\title{
Uji Efektivitas Sediaan Gel Ekstrak Biji Kelengkeng (Euphoria Longan) Terhadap Luka Bakar Pada Punggung Kelinci Putih Jantan
}

\author{
Ade Irma Fitria Ningsih ${ }^{1 *}$, Hardiono Adisaputra ${ }^{1}$, Novia Aqsa ${ }^{1}$ \\ ${ }^{1}$ Jurusan Ilmu Farmasi, Universitas Nahdlatul wathan, Mataram, Indonesia \\ *Email : adefitriningsih80@gmail.com
}

\begin{abstract}
Abstrak : Pengobatan tradisional merupakan salah satu cara yang aman untuk mengobati luka bakar. Salah satu tanaman yang digunakan untuk pengobatan luka bakar yaitu biji kelengkeng. Penelitian ini bertujuan untuk mengetahui efektivitas gel ekstrak biji kelengkeng terhadap luka bakar pada kulit punggung kelinci putih jantan dengan konsentrasi ekstrak 5\%, 10\%, 15\% dan sediaan tanpa ekstrak (control negatif). Sediaan gel yang diperoleh di uji efektivitasnya dalam penutupan diameter luka bakar pada kulit punggung kelinci putih jantan. Data yang diperoleh ditentukan nilai AUC kemudian dianalisis statistic dengan SPSS versi 16 menggunakan ANOVA dengan taraf kepercayaan $95 \%$.

Hasil penelitian menunjukkan bahwa aktivitas penutupan diameter luka bakar yang paling cepat yaitu gel ekstrak 10\%. Berdasarkan hasil statistik perlakuan gel ekstrak 10\% berbeda bermakna dengan control negatif $(p<0,05)$ dan tidak berbeda bermakna dengan perlakuan control positif bioplacenton $(p>0,05)$.
\end{abstract}

Kata kunci : Ekstrak Biji Kelengkeng (Euphoria longan), Luka bakar, Kelinci

\section{Pendahuluan}

Penyebab luka bakar yang paling sering terjadi adalah terbakar api langsung yang dapat dipicu atau disebabkan oleh cairan yang mudah terbakar contohnya bensin, gas kompor rumah tangga, cairan dari tabung pemantik api, sehingga menyebabkan luka bakar pada seluruh atau sebagian lapisan kulit, sehingga banyak penderita luka bakar yang melakukan respon penolakan sebagai bentuk akibat dari kecacatan yang ditimbulkan oleh luka bakar. (Gowri et al., 2010).

Menurut data World Health Organization (WHO) (2014 )memperkirakan terdapat 265.000 kematian yang terjadi setiap tahunnya diseluruh dunia akibat luka bakar.Pada tahun 2013 prevalensi luka bakar di Indonesia telah mengalami penurunan sebesar $1,5 \%$ dibandingkan tahun 2008. Provinsi dengan prevalensi tertinggi adalah Papua dan Bangka Belitung (Depkes, 2013), dengan penyebab terbanyak adalah flame burn injury $(50,4 \%)$.

Tantangan terbesar penyembuhan luka bakar hingga menyebabkan mortalitas adalah lamanya proses penyembuhan dan terjadinya infeksi (Perdanakusuma, 2007).Pengobatan yang dikenal dalam dunia kesehatan adalah pengobatan dengan sintetik maupun pengobatan alamiah (Triana dan Nurhidayat, 2006). Obat sintetik yang sering digunakan adalah Silver Sulfadiazine, Bioplacenton, Hidrogell (Rovikoh, 2011).Akan tetapi penggunaan obat sintetik tidak jarang menimbulkan reaksi pada kulit seperti terjadinya iritasi dan rasa perih pada permukaan kulit, sehingga masyarakat kembali menggunakan obat dari bahan alam.
Pengobatan secara tradisional merupakan salah satu cara yang aman untuk mengobati luka bakar. Salah satu tanaman yang dapat dimanfaatkan untuk pengobatan luka bakar yaitu biji kelengkeng (Euphoria longan), di Dusun Peresak, Desa Sepakek, Kabupaten Lombok Tengah, biji kelengkeng digunakan secara empiris untuk menyembuhkan luka dengan cara dibakar dan ditumbuk, serbuk arang biji kelengkeng dicampurkan dengan minyak kelapa kemudian dibalurkan pada luka memar ataupun luka akibat terkena benda panas.

Menurut Morton (1987), di Vietnam biji kelengkeng digunakan dengan mememarkan biji untuk mengatasi luka bakar dan dapat mengobati luka akibat gigitan ular karena diyakini dapat menyerap bisa ular. Selain itu senyawa fenolik dan flavonoid pada ekstrak etanol biji kelengkeng memiliki aktivitas antibakteri terhadap E. coli dan S. aureus (Santi, RN. et al., 2011). Hal ini diperkuat oleh penelitian Syarifah (2010) yang menyebutkan bahwa minyak atsiri dari biji kelengkeng berpotensi sebagai antibakteri terhadap Escherichia coli dengan nilai KHM sebesar 45,74\%.Adapun zat aktif yang terdapat pada biji kelengkeng adalah senyawa golongan fenolik, flavonoid, saponin, minyak atsiri (Santi, RN. et al., 2011) dan tannin (Fauziah, 2015).

Berdasarkan penelitian sebelumnya flavonoid merupakan senyawa aktif yang dapat menghambat pertumbuhan bakteri pada jaringan hidup (Harris, 2011), senyawa flavonoid bekerja sebagai antibakteri dengan mekanisme kerja mendenaturasi protein sel bakteri sehingga dapat merusak dinding sel bakteri dan tidak bisa diperbaiki lagi (Muthalib et al., 2013). Selain itu saponin dan tannin dapat memicu angiogenesis 
(Majewska dan Gendaszewska, 2011; Li et al., 2011) senyawa saponin mekanisme kerjanya memicu pembentukan kolagen lebih cepat sehingga luka bakar dapat sembuh lebih cepat (Mappa, et al., 2013), sementara tannin secara garis besar mekanismenya adalah dengan merusak membran sel bakteri (Akiyama, et al., 2010) senyawa tannin dapat mengkerutkan dinding sel bakteri sehingga mengganggu permeabilitas sel sehingga pertumbuhannya terhambat. Mekanisme kerja minyak atsiri dengan cara mengganggu proses terbentuknya membran atau dinding sel bakteri sehinnga tidak dapat terbentuk atau terbentuk tidak sempurna (Ajizah, 2014).

Atas dasar pertimbangan diatas maka dianggap sangat penting untuk dilakukan uji efektivitas sediaan gel ekstrak biji kelengkeng (euphoria longan) terhadap luka bakar pada punggung kelinci putih jantan

\section{Metode Penelitian}

Penelitian ini merupakan jenis penelitian true eksperimental dengan rancangan Pre and Post Test Controlled Group Design yaitu jenis penelitian yang melakukan pengamatan terhadap kelompok kontrol dan perlakuan sebelum dan sesudah di beri perlakuan (Notoatmodjo, 2012).

Alat yang digunakan pada penelitian ini antara lain : timbangan analitik, beaker gelas, gelas ukur, pipet tetes, batang pengaduk dan tabung reaksi.Alat pada penelitian yang bersifat teknis antara lain : bejana maserasi, aluminium foil, penggaris, sarung tangan, alat ukur, mortir dan stampher, kandang kelinci, gunting dan lempengan besi.

Bahan yang digunakan pada penelitian antara lain etanol $70 \%$ (v/v).Bahan pada penelitian yang bersifat teknis antara lain aquadest, Bioplacenton, kloroform dan kelinci $N E W$ ZEALAND putih jantan.

1. Penyiapan Sampel (Ekstrak Etanol $70 \%$ Biji Kelengkeng)

a. Tahap pengambilan dan pengolahan sampel Biji kelengkeng yang akan digunakan dalam proses ekstraksi dipisahkan dari daging buahnya dan dibersihkan dari pengotor lainnya.

b. Tahap pengubahan bentuk/pengecilan ukuran biji kelengkeng

c. Biji kelengkeng yang sudah dibersihkan dari pengotor lainnya kemudian dikeringkan di bawah sinar matahari secara tidak langsung, yakni dengan ditutupi kain hitam diatasnya, tujuan dikeringkan yaitu untuk mengurangi kadar air yang ada pada simplisia tersebut.

d. Biji kelengkengyang sudah kering tersebut di lakukan pengubahan bentuk/pengecilan ukuran sampai ukuran yang paling kecil dengan cara diempingkan dengan menggunakan palu, yaitu bertujuan untuk menambah ukuran padatan sehingga pada saat penambahan bahan lain pencampuran dapat dilakukan secara merata.
2. Pembuatan ekstrak etanol $\mathbf{7 0 \%}$ biji kelengkeng

a. Penimbangan dan pembuatan ekstrak biji kelengkeng (Euphoria longan) dengan menggunakan cairan penyari yaitu etanol $70 \%$.

b. Biji kelengkeng yang sudah kering dan sudah di lakukan pengubahan bentuk berupa serbuk halus tersebut kemudian ditimbang sebanyak 200 gram dengan cairan penyari yang dipakai sebanyak $1500 \mathrm{ml}$ etanol 70\%, dan dimasukkan kedalam bejana maserasi.

c. Simplisia dibasahi dengan cairan penyari sedikit demi sedikit sambil diaduk menggunakan batang pengaduk hingga semua bagian simplisia basah merata.

d. Simplisia yang sudah terendam dengan cairan penyari didalam bejana maserasi di simpan selama 7 hari pada suhu kamar dan terlindung dari cahaya matahari, bejana di tutup dengan menggunakan aluminium foil.

\section{Penguapan Ekstrak}

Penguapan ekstrak dilakukan dengan menggunakan evaporator tujuan dilakukannya penguapan untuk menghilangkan cairan penyari yang digunakan dan untuk mendapatkan ekstrak kental.

4. Pembuatan Sediaan Gel

a. Semua bahan disiapkan

b. Bahan ditimbang sesuai dengan formula dan konsentrasi yang telah ditentukan.

c. Ekstrak dilarutkan dalam sebagian air, kemudian dipanaskan pada suhu $50^{\circ} \mathrm{C}$.

d. Ditambahkan Na-CMC dan diaduk hingga homogen.

e. Ditambahkan Gliserin, Propilenglikol dan air kemudian diaduk kontinyu hingga terbentuk gel.

f. Gel yang telah terbentuk kemudian dimasukkan kedalam wadah dan disimpan pada tempat yang gelap dan dingin selama semalam.

g. Selanjutnya dilakukan evaluasi terhadap sediaan gel

5. Pembuatan Luka Bakar

a. Hewan uji yang digunakan yaitu kelinci putih jantan jenis New Zealand dengan berat badan 1,5-3 kg sebanyak 5 ekor.

b. Bulu hewan uji yang akan digunakan kemudian dicukur dibagian punggungnya

c. Hewan uji dimasukkan kedalam kandang untuk dilakukan anastesi inhalasi menggunakan kloroform untuk mengurangi kesadaran hewan uji

d. kemudian ditempelkan lempengan besi dengan diameter $1,5 \mathrm{~cm}$ selama 5 detik yang telah dipanaskan selama 1 menit, dilakukan sampai mencapai bagian atas dermis (derajat 2)

e. Luka bakar yang telah terbentuk kemudian dioleskan gel ekstrak biji kelengkeng 2 kali sehari setiap pagi dan sore hari

f. Pengukuran diameter luka bakar dilakukan setiap hari dimulai hari kedua menggunakan penggaris (Hasyim., et al., 2012) 


\section{Hasil dan Pembahasan}

\section{Hasil Pengamatan Diameter Luka Bakar Pada Hewan Uji Kelinci}

Berdasarkan hasil pengamatan diameter luka bakar pada hewan uji kelinci putih jantan selama 7 hari dengan melakukan pengukuran diameter luka bakar dari hari pertama sampai hari ke-tujuh, hasil yang diperoleh dalam penelitian ini sebagai berikut:

Tabel 1. Hasil Rata-Rata Pengamatan Diameter Luka Bakar

\begin{tabular}{|c|c|c|c|c|c|c|c|c|c|c|}
\hline \multirow[t]{3}{*}{ No } & \multirow[t]{3}{*}{$\begin{array}{l}\text { Kelompok } \\
\text { perlakuan }\end{array}$} & \multirow{3}{*}{$\begin{array}{c}\text { Diameter } \\
\text { luka } \\
\text { bakar } \\
\text { sebelum } \\
\text { perlaknan } \\
(\mathrm{cm}) \\
\end{array}$} & \multicolumn{8}{|c|}{$\begin{array}{c}\text { Rata-rata diameter luka bakar setelah } \\
\text { perlakuan }(\mathrm{cm})\end{array}$} \\
\hline & & & \multicolumn{8}{|c|}{ Harike- } \\
\hline & & & 0 & 1 & 2 & 3 & 4 & 5 & 6 & 7 \\
\hline 1 & $\begin{array}{l}\text { Kontrol } \\
\text { negatif }\end{array}$ & 2,2 & 2,2 & 2,2 & 2,2 & 2.0 & 1,9 & 1,8 & 1,7 & 1,6 \\
\hline 2 & $\begin{array}{l}\text { Kontrol } \\
\text { positif }\end{array}$ & 2,2 & 2,2 & 2,2 & 2,1 & 1,9 & 1,8 & 1,6 & 1,5 & 1,4 \\
\hline 3 & Ekstrak $5 \%$ & 2,2 & 2,2 & 2,2 & 2,2 & 2,0 & 1,9 & 1,7 & 1,6 & 1,5 \\
\hline 4 & Ekstrak $10 \%$ & 2,2 & 2,2 & 2,2 & 2,1 & 1,8 & 1,7 & 1,5 & 1,3 & 1,2 \\
\hline 5 & Ekstrak $15 \%$ & 2,2 & 2,2 & 2,2 & 2,1 & 1,9 & 1,8 & 1,6 & 1,5 & 1,3 \\
\hline
\end{tabular}

Tabel 1 menunjukkan bahwa rata-rata diameter penutupan luka bakar dengan perlakuan kontrol negatif mampu mengurangi diameter luka bakar menjadi $1,6 \mathrm{~cm}$, kontrol positif mampu mengurangi diameter luka bakar menjadi $1,4 \mathrm{~cm}$, sediaan gel dengan konsentrasi ekstrak 5\% mampu mengurangi diameter luka bakar menjadi $1,5 \mathrm{~cm}$, sediaan gel dengan konsentrasi ekstrak $10 \%$ mampu mengurangi diameter luka bakar menjadi $1,2 \mathrm{~cm}$, sediaan gel dengan konsentrasi ekstrak $15 \%$ mampu mengurangi diameter luka bakar menjadi $1,3 \mathrm{~cm}$.

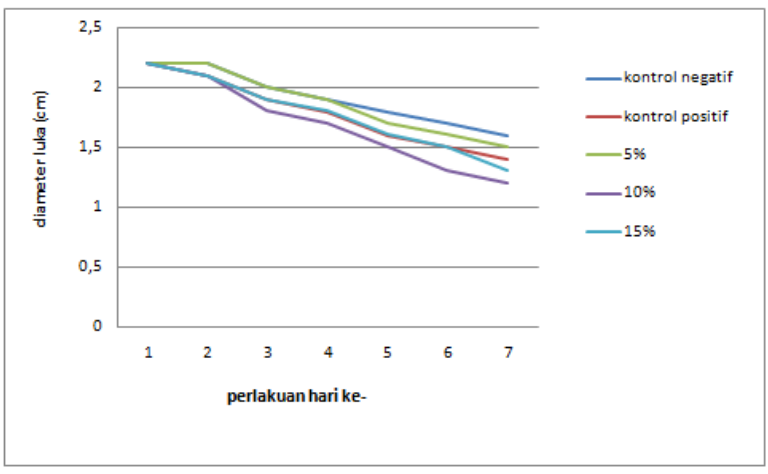

Gambar 1. Grafik pengurangan diameter luka

Gambar 1 menunjukkan bahwa kelima kelompok perlakuan dapat mengurangi diameter luka bakar dalam waktu tujuh hari, sediaan gel dengan konsentrasi ekstrak 10\% mengurangi diameter luka bakar lebih cepat dibandingkan dengan sediaan gel dengan konsentrasi ekstrak $15 \%, 5 \%$, kontrol positif dan kontrol negatif.

\section{Hasil Analisis Data}

Data hasil pengamatan diameter luka bakar pada hewan uji ini kemudian dihitung nilai AUC (Area Under Curve).

\section{Tabel 2. Data Hasil Perhitungan AUC}

\begin{tabular}{|c|c|c|}
\hline No & $\begin{array}{c}\text { Kelompok } \\
\text { Perlakuan }\end{array}$ & $\begin{array}{c}\text { Nilai Rata-rata } \\
\text { AUC }\end{array}$ \\
\hline 1. & Kontrol negatif & 13,98 \\
2. & Kontrol positif & 13,16 \\
3. & Gel ekstrak 5\% & 13,59 \\
4. & Gel ekstrak 10\% & 12,5 \\
5. & Gel ekstrak 15\% & 13,04 \\
\hline
\end{tabular}

Tabel 2. menunjukkan nilai rata-rata AUC pengurangan diameter luka bakar pada hewan uji dari hari pertama sampai dengan hari ke tujuh dengan lima pengulangan menggunakan 5 hewan uji kelinci putih jantan.

\section{Tabel 3. Hasil Uji Normalitas dan Uji Varians}

\begin{tabular}{|c|c|c|c|}
\hline No & $\begin{array}{c}\text { Kelompok } \\
\text { Perlakuan }\end{array}$ & $\begin{array}{c}\text { Shapiro } \\
\text { Wilk }\end{array}$ & Varians \\
\hline 1 & Kontrol negatif & 0,311 & \\
2 & Kontrol positif & 0,199 & \\
3 & Ekstrak 5\% & 0,312 & 0,254 \\
4 & Ekstrak 10\% & 0,369 & \\
5 & Ekstrak 15\% & 0,920 & \\
\hline
\end{tabular}

Tabel 3 menunjukkan hasil uji Shapiro Wilk setiap kelompok perlakuan memiliki nilai $\mathrm{p}>0,05$ yang menunjukkan bahwa data setiap kelompok perlakuan berdistribusi normal dan nilai uji varians p > 0,05 yang menunjukkan bahwa setiap kelompok perlakuan memiliki varians yang sama (homogen) sehingga mencukupi persyaratan data untuk dapat diuji dengan uji anova.

\section{Tabel 4. Hasil One Way Anova}

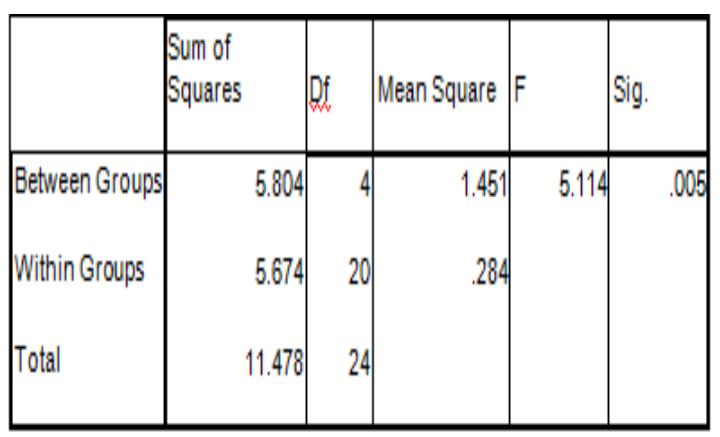

Tabel 4 menunjukkan bahwa hasil uji anova diperoleh nilai $\mathrm{p}(0,005)<0,05$ yang artinya, "paling tidak terdapat dua kelompok perlakuan yang berbeda bermakna" sehingga dilanjutkan dengan melakukan analisis post hoc. 
Tabel 5. Hasil Uji Post Hoc

\begin{tabular}{|c|c|c|c|}
\hline No. & Kelompok perlakuan & Sig. & Keterangan \\
\hline 1 & Kontrol negatif - kontrol positif & 0,024 & Berbeda bermakna \\
\hline 2 & Kontrol negatif - ekstrak 5\% & 0,095 & Tidak berbeda \\
\hline 3 & Kontrol negatif - ekstrak 10\% & 0,000 & Berbeda bermakna \\
\hline 4 & Kontrol negatif - ekstrak 15\% & 0,011 & Berbeda bermakna \\
\hline 5 & Kontrol positif - ekstrak 5\% & 0,503 & Tidak berbeda \\
\hline 6 & Kontrol positif - ekstrak 10\% & 0,064 & Tidak berbeda \\
\hline 7 & Kontrol positif - ekstrak 15\% & 0,725 & Tidak berbeda \\
\hline 8 & Ekstrak 5\% - ekstrak 10\% & 0,016 & Berbeda bermakna \\
\hline 9 & Ekstrak 5\% - ekstrak 15\% & 0,311 & Tidak berbeda \\
\hline 10 & Ekstrak 10\% - ekstrak 15\% & 0,125 & Tidak berbeda \\
\hline
\end{tabular}

Tabel 5 menunjukkan hasil analisis post hoc dan diperoleh hasil yaitu kelompok kontrol negatif dengan kontrol positif $\mathrm{p}=0,024$, kelompok kontrol negatif dengan ekstrak 5\% $\mathrm{p}=0,095$, kelompok kontrol negatif dengan ekstrak $10 \% \mathrm{p}=0,000$, kelompok kontrol negatif dengan ekstrak $15 \% \mathrm{p}=$ 0,011, kelompok kontrol positif dengan ekstrak 5\% $\mathrm{p}=0,503$, kelompok kontrol positif dengan ekstrak $10 \% \mathrm{p}=0,064$, kelompok kontrol positif dengan ekstrak $15 \% \mathrm{p}=0,725$, kelompok kontrol ekstrak $5 \%$ dengan ekstrak $10 \% \mathrm{p}=0,016$, kelompok kontrol ekstrak 5\% dengan ekstrak 15\% p = 0,311, kelompok kontrol ekstrak $10 \%$ dengan ekstrak $15 \%$ $\mathrm{p}=0,125$.

Pengujian efektivitas gel ekstrak biji kelengkeng terhadap diameter luka bakar digunakan lima ekor kelinci putih jantan dengan masing-masing perlakuan satu ekor kelinci dibuat lima luka bakar dengan diameter 2,2 cm menggunakan lempengan besi yang dipanaskan selama kurang lebih 1 menit kemudian ditempelkan pada punggung kelinci sampai dengan melukai lapisan kulit terluar.

Sediaan gel tanpa ekstrak dibuat sebagai kelompok kontrol negatif untuk dapat membandingkan efektivitas sediaan gel dengan konsentrasi ekstrak 5\%, 10\% dan 15\%, selain itu peneliti juga memilih produk obat luka bakar bioplacenton yang beredar dipasaran sebagai kelompok kontrol positif.

Hasil uji statistik menunjukkan bahwa data kelompok perlakuan bersifat homogen dan berdistribusi normal sehingga data tersebut dianalisis menggunakan uji anova. Data yang dimasukkan kedalam program SPSS adalah nilai total AUC dari setiap kelompok perlakuan, selanjutnya dilakukan uji parametrik menggunakan anova.

Interpetasi hasil dari tabel anova menunjukkan bahwa nilai $\mathrm{p}(0,005)<0,05$ yang berarti bahwa "paling tidak ada dua kelompok perlakuan yang berbeda bermakna" selanjutnya untuk mengetahui kelompok yang berbeda bermakna tersebut dilakukan uji lanjutan post hocmenggunakan uji LSD.

Hasil uji Post Hocmenunjukkan kelompok perlakuan kontrol negatif dengan kontrol positif adalah berbeda bermakna, yang artinya ada perbedaan efek antara keduanya. Perlakuan antara kontrol negatif dengan sediaan gel konsentrasi ekstrak 5\% adalah tidak berbeda, yaitu tidak ada perbedaan efek antara kedua kelompok perlakuan tersebut. Perlakuan kontrol negatif dengan sediaan gel konsentrasi ekstrak $10 \%$ dan $15 \%$ menunjukkan hasil berbeda bermakna, yang artinya ada perbedaan efek antara kedua kelompok perlakuan tersebut.

Kelompok perlakuan antara kontrol positif dengan sediaan gel dengan penambahan ekstrak $5 \%, 10 \%$ dan $15 \%$ adalah tidak berbeda, dengan kata lain ketiga kelompok perlakuan tersebut memiliki efek yang mirip dengan perlakuan kontrol positif. Kelompok perlakuan antara sediaan gel konsentrasi ekstrak 5\% dengan sediaan gel konsentrasi ekstrak $10 \%$ adalah berbeda bermakna, yaitu ada perbedaan efek yang ditimbulkan antara perlakuan sediaan gel ekstrak 5\% dengan sediaan gel ekstrak $10 \%$. Kelompok perlakuan sediaan gel konsentrasi ekstrak 5\% dengan sediaan gel konsentrasi ekstrak $15 \%$ adalah tidak berbeda. Kelompok perlakuan sediaan gel konsentrasi ekstrak $10 \%$ dengan sediaan gel konsentrasi ekstrak $15 \%$ adalah tidak berbeda bermakna, yang artinya tidak ada perbedaan efek antara keduanya.

Dengan demikian, sediaan yang lebih efektif yaitu sediaan dengan konsentrasi ekstrak $10 \%$ dibandingkan dengan sediaan dengan konsentrasi ekstrak 5\% dan 15\%, hal ini tidak sejalan dengan hasil penelitian sebelumnya dengan Judul Formulasi Sediaan Gel Basis $\mathrm{Na}-\mathrm{CmC}$ Ekstrak Etanol Daun Cocor Bebek Sebagai Penyembuh Luka Bakar Pada Kelinci,bahwa semakin tinggi konsentrasi ekstrak maka obat yang terabsorbsi semakin banyak dan penyembuhan luka semakin cepat (Istiana, S., 2016). Hal tersebut dapat disebabkan oleh pengaplikasian sediaan dengan konsentrasi ekstrak yang tinggi pada permukaan luas luka yang kecil akan menyebabkan terjadinya penumpukan sediaan pada lapisan atas membran, sehingga zat aktif tidak sepenuhnya terlepas dari sediaan dan hanya tertinggal pada permukaan kulit (Simanjuntak 2005).

Kelompok perlakuan kontrol negatif juga memiliki kemampuaan untuk mengurangi diameter luka bakar, hal ini terjadi secara normal dikarenakan peran sel fibrolas yang akan aktif 
bergerak dari jaringan sekitar luka kedalam daerah luka, kemudian akan berkembang (proliferasi) dan menghasilkan kolagen yang berperan dalam membangun jaringan baru, tetapi hal ini membutuhkan waktu yang lebih lama(Ningsih, S., et al., 2015).

\section{Kesimpulan}

a. Gel ekstrak biji kelengkeng (Euphoria longan) memiliki aktivitas sebagai obat luka bakar pada kulit punggung kelinci putih jantan.

b. Gel ekstrak biji kelengkeng (Euphoria longan) dengan konsentrasi ekstrak 5\% mampu mengurangi diameter luka bakar dari dari 2,2 $\mathrm{cm}$ menjadi $1,5 \mathrm{~cm}$, sedangkan sediaan gel dengan konsentrasi ekstrak 10\% mampu mengurangi diameter luka bakar dari $2,2 \mathrm{~cm}$ menjadi $1,2 \mathrm{~cm}$ dan sediaan gel dengan konsentrasi ekstrak 15\% mampu mengurangi diameter luka bakar dari $2,2 \mathrm{~cm}$ menjadi $1,3 \mathrm{~cm}$.

\section{Daftar Pustaka}

Ajizah, A. 2014. Sensitivitas Salmonella typhimurium terhadap Ekstrak Daun Psidium Guajava L. Bioscientiae, 1 (1) : 3138

Depkes RI. 2013. Riset Kesehatan Dasar. Jakarta: Badan Penelitian dan pengembangan Kesehatan Kementrian Kesehatan RI.

Fauziah, W. N. 2015. UjiAktivitas Antimikroba Ekstrak Etanol Daun, Kulit dan Biji Kelengkeng (Euphoria longan) Terhadap Pertumbuhan Saccaromyces ceresiviae Dan Lactobacillus plantarum Penyebab Kerusakan Nira Siwalan (Borassus flabellifer L.). Skripsi. Malang: UIN Maulana Malik Ibrahim.

Gowri, S. S., \& Vasantha, K. 2010. Phytochemical Screening and Antibacterial Activity of Syzygium cumini (L.) (Myrtaceae) Leaves Extracts. International Journal of PharmTech Research , 1569-1573

Haris, M. 2011. Penentuan Kadar Flavanoid Total dan Aktivitas Antioksidan Dari Getah Jarak Pagar Dengan spektrofotometer UVVisibel.SkripsiFakultas Farmasi. Universitas Anadalas. Padang.

Majewska, I. dan Gendaszewska, E, 2011 ProangiogenicActivity of Plant Extracts in Acceleraty Woundhealing- A New Face of Old Phytomedicine,ACTA ABP Biochimica Polonica, Vol. 58, 449-460.

Mappa, T.Edy, H.J., Kojong, N. 2013. Formulasi Gel Ekstrak Daun Sasaladahan (Peperomia pellucida (L.) H.B.K) dan Uji Efektivitasnya Terhadap Luka bakar pada Kelinci (Oryctolagus cuniculus). UNSRAT, volume $2(2)$

Morton, J. 1987. Fruits Of Warm Climates : Longan, P. 259-262. Miami, FL, Refrensi : http://www.hort.purdve.edu,

diakses tangggal 3 februari 2017

Ningsih, S., Paturusi, A.A.E., Amalia, N.R. 2015. Uji Efek Penyembuhan Gel Ekstrak Daun Jarak Merah (Jatropha gossypifolia Linn.) Terhadap Luka Sayat Pada Kelinci. JF FIK UINAM, Volume 3 (3).

Notoatmodjo . 2012. Metode Penelitian Kesehatan. Jakarta : Rineka Cipta

Perdanakusuma, D.S. 2007. Anatomi Fisiologi Kulit dan Penyembuhan Luka. Airlangga university School Of Medicine. Dr. Soetomo general Hospital. Surabaya

Rovikoh, 2011. Formulasi Sediaan Gel Ekstrak Lidah Buaya (Aloe Vera (L.) Webb.) Dengan Gelling Agent Hidroksipropil Metil Selulosa Dan Uji Efek Penyembuhan Luka Bakar. Skripsi Thesis, Universitas Muhammadiyah Surakarta.

Santi, RN.,Muhtadi., Indrayudha P. 2011. Aktivitas Antibakteri Ekstrak Etanol Kulit dan Biji Kelengkeng (Euphoria longan (Lour) Steud) Terhadap Escherichia coli dan Staphylococcus aureus serta Toksisitasnya Terhadap Artemia salina Leach. Pharmacon, volume 12 (1) : 33 - 39 .

Simanjuntak, M.T. 2005. Biofarmasi Sediaan Yang Diberikan Melalui Kulit. Medan: Universitas Sumatera Utara.

Triana, E., N. Nurhidayat. 2006. Pengaruh Pemberian Beras yang di Fermentasi oleh Monascus purpureus Jmba Terhadap Darah Tikus Putih (Rattus sp.) Hiperkolesterolemia. Biodiversitas 7 (4) : 317-321

WHO. 2014. Health for the World's Adolescents: A Second Chance in the Second Decade. Geneva, World Health Organization Departemen of Noncommunicable disease surveillance. 